\title{
Drivers and barriers for municipal retrofitting activities - Evidence from a large-scale survey of German local authorities
}

\author{
Friedemann Polzin $^{\mathrm{a}, *}$, Colin Nolden ${ }^{\mathrm{b}}$, Paschen von Flotow ${ }^{\mathrm{c}}$ \\ ${ }^{\text {a }}$ Utrecht University School of Economics (U.S.E.), Sustainable Finance Lab (SFL), Kriekenpitplein 21-22, 3584 EC Utrecht, The Netherlands \\ ${ }^{\mathrm{b}}$ University of Bristol Law School, 8-10 Berkeley Square, Bristol, BS8 1HH, United Kingdom \\ ${ }^{\mathrm{c}}$ Sustainable Business Institute (SBI), Zehnthofstr. 1, 65375 Oestrich-Winkel, Germany
}

\section{A R T I C L E I N F O}

\section{Keywords:}

Energy efficiency

Retrofitting

Local authorities

LED

Lighting

\begin{abstract}
A B S T R A C T
Local authorities are key actors for implementing innovative energy efficiency technologies (retrofitting) to reduce end-use energy demand and consequently reduce negative effects of high energy use such as climate change and public budget deficits. This paper reports the results of a large-scale survey of German municipalities by assessing drivers and barriers for deploying LED street lighting as an example of innovative retrofits. The results indicate that competencies and capacities, transparency of the underlying technology base, and a clear proposition of savings are crucial drivers for municipal retrofitting engagement. Most significant barriers include lack of experience, the tendency to wait for future improvements of innovative energy efficiency technologies, and existing contracts with energy suppliers, manufacturers, or other conventional retrofitting contractors. Investments in municipal competency building (both regarding technologies and procurement) as well as diffusing standard tendering criteria and (public) monitoring of their effectiveness are highly recommended to accelerate the municipal modernization process.
\end{abstract}

\section{Introduction}

Reducing energy demand by implementing novel energy efficiency technologies represents one solution to combatting climate change while also reducing energy costs, fossil-fuel dependency and related issues such as energy insecurity and fuel poverty [22,23,41,51,53]. Municipalities play a central role implementing measures that reduce end-use energy demand (EUED) and deliver more efficient energy services as they are often the proprietors of aging infrastructure [21,42,51,54].

Many modernization (retrofitting) activities are driven by the need to increase energy and cost effectiveness, to tackle climate change, to reduce budgetary deficits, to maintain adequate levels of public services or to comply with increasing regulation $[48,51,52]$. Qualitative, casestudy based research points towards technological factors (e.g. quality, durability and missing standards), economic factors (high upfront costs, transaction costs and uncertain future energy costs), competency factors (for procurement and management of retrofits) and institutional factors (such as public infrastructure maintenance backlog) hindering retrofitting activities [36,42,51,52,60].

Quantitative analysis of drivers and barriers for retrofitting, on the other hand, have been lacking $[42,49,51,52]$. Statistically backed recommendations for local authority administrations and national policy makers are required to enhance and accelerate retrofitting activities in municipalities (see for example [38]). Based on a review of recent studies published, our research question reads as follows: Which factors enable or prevent local authorities (municipalities) from modernising energy infrastructures?

We analyse the case of LED (light-emitting diodes) street lighting in Germany. Street lighting in Germany, as in many other countries, represents a major cost factor, accounting for almost one third of municipal electricity budgets [11,7]. With municipal debt in Germany amounting to $152.71 \mathrm{bn}$ EUR in 2016 or $13.4 \mathrm{~m}$ EUR per local authority $[13,14]$, LED streetlights, with energy efficiency gains of up to $90 \%$ compared to conventional light bulbs, provide an innovative and costeffective retrofitting option $[16,3,7]$. Modernising public street lighting appliances allows municipalities to reduce end-use energy demand and costs and to alleviate budget constraints [10].

The remainder of this paper is structured as follows: The next section (Section 2) contains a literature review. Section 3 develops the hypotheses based on theoretical insights. Section 4 introduces the methodology. Section 5 reviews the results of the quantitative survey analysis. Section 6 discusses our findings and concludes this paper by deriving policy implications.

\footnotetext{
* Corresponding author.

E-mail address: f.polzin@uu.nl (F. Polzin).
} 


\section{Literature review}

Financing, operating and maintaining public sector properties is a global challenge $[18,44,9]$. At the same time, local authorities and cities in particular find themselves increasingly at the heart of global energy and climate change action [21]. Although maintenance backlogs and aging infrastructure may place increasing strains on limited resources, retrofitting and energy performance improvements provide windows of opportunities to procure innovative retrofits and services given the relatively large municipal responsibility to minimise costs while guaranteeing investment and climate action [36,40,55,6].

However, modernization activities using innovative EUED technologies ('retrofitting') require significant upfront investments and enhanced capacities to evaluate different types of LED, integrate LED into the existing infrastructure and set up intelligent lighting systems. Our qualitative research [42] on municipal retrofitting governance suggests that designing the content of tenders to include cost transparency and open-book accounting is an important determinant for competition among organisational (governance) structures ${ }^{1}$ which often determine retrofitting investment and capacities. Depending on the local situation, especially in the absence of appropriate skills and institutions, outsourcing using Energy Service Companies (ESCOs) may help accelerate the retrofitting process [42]. Our quantitative research [43] suggests that the cost of outsourcing may be higher if in-house competencies and capacities as well as existing partnerships are sufficient to engage in innovative retrofitting activities [43]. Both papers indicate that market transparency and municipal capacities play an important role in accelerating retrofitting activities by allowing municipal representatives to make rational choices among modes of governance most suitable for their specific retrofitting priorities $[42,43]$.

The role of intermediaries is particularly relevant in this context as they raise awareness and lower transaction costs for non-hierarchical (as opposed to in-house/hierarchical) options [36,42,43]. The number of drivers increasing municipal engagement with retrofitting in general is increasing rapidly. These include the emergence of public procurement frameworks that reduce the transaction costs for both the public sector and contractors in the UK [35,36], innovative business models mimicking 20-year power purchase agreements such as MEETS (Measured Energy Efficiency Transaction Structures) in the US [35] and the increasing drive towards making energy efficiency projects 'investor ready' internationally, such as the Investor Confidence Project ${ }^{2}[35,36]$.

Despite innovations in the retrofitting/energy efficiency service market there are still many barriers to overcome, mostly linked to high transaction costs arising out of uncertain returns on investment and payback periods linked to a lack of verified information on quality, energy savings and longevity of new retrofits (such as LED) [25,51,52]. Below, drivers and barriers for retrofitting in the municipal context are discussed.

\section{Hypotheses}

This section provides an overview of the hypotheses regarding drivers and barriers for retrofitting derived from the literature.

\subsection{Drivers for retrofitting (using EUEDs-LED)}

First, enhanced competencies, such as those described above, stimulate the procurement of innovative (green) goods and services to improve energy performance $[35,36]$. These competencies were previously not necessary because more efficient energy technologies in the

\footnotetext{
${ }^{1}$ In this context modes of governance refers to how transactions are organised through governance structures where in-house refers to complete control over the procurement and retrofitting process and long-term performance contracts refer to outsourcing $[42,59]$.

2 see http://www.eeperformance.org/.
}

lighting industry evolved slowly ([16,47,7]; for an extended review see [15]). In the case of local authorities, staff only needed to replace the lightbulbs without changing the adjacent infrastructure. Hence, local authority competencies regarding tendering and implementation of retrofitting are crucial [42].

H1a: Higher municipal competencies (technical knowledge) increase engagement in retrofitting activities.

Second, potential savings result from the application of innovative EUEDs (in this case LEDs yield 90\% efficiency gains and associated energy and cost reductions compared to conventional lighting depending on drivers and other components) [3,7]. Hence, we hypothesize that this is one important incentive for engaging in retrofitting activities [42,52]. This is supported by research on consumers [34]. In addition, these savings need to be verified to plan and implement retrofitting measures [40].

H1b: The larger the potential saving (anticipated savings / financial return), the greater the interest in retrofitting.

H1c: Measurement and verification of these savings drive engagement in retrofitting activities

LEDs as innovative technologies are still more expensive than conventional lighting technologies which leads to a longer payback period for retrofits [16]. Public support programs represent a driver for the implementation of novel EUEDs [8], energy efficiency investments [52] and low-carbon innovation in general [41].

H1d: Subsidies/support schemes constitute a driver for retrofitting activities.

To further support the planning and implementation process, previous research has highlighted the importance of consultants (facilitators) in filling the knowledge gap that municipalities face regarding retrofitting activities and specific innovative technologies [31,36]. Our quantitative study on the topic found that consultants discourage outsourcing of retrofitting activities while maintaining their role as drivers for in-house municipal initiatives [43].

H1e: Engagement of a consultant increases the likelihood of retrofitting the public lighting infrastructure

Our final hypothesis builds on the fact that behaviour plays a significant role in saving energy. Previous research has found that decision makers do not necessarily act rationally when it comes to assessing costs and benefits $[26,51,52]$. Despite the expectation that investment opportunities in energy with a reasonable payback time will be realized, political will and support remain important drivers for retrofitting activities $[42,46]$.

H1f: Political will and support determine a municipality's engagement in retrofitting.

\subsection{Barriers to retrofitting (using $L E D$ )}

Major factors limiting municipal engagement with innovative EUED are linked to their technological nature, such as their diversity and widespread application, small scale and low visibility $[52,60]$. From the procurement literature $[37,49,52,55]$, we derive that potential users require enhanced knowledge to evaluate, plan and implement innovative EUEDs [55]. Also, the management of retrofitting processes requires enhanced capabilities i.e. for neutral and cost-transparent tenders as well as measurement and verification $(\mathrm{M} \& \mathrm{~V})$ once the technology has been installed $[18,40,55]$.

H2a: Missing personnel capacities limit engagement in retrofitting activities.

A central barrier to the adoption of new technologies in the 
innovation diffusion literature is the lack of opportunity to try the new product and gain experience ('trialability', see [45,46,52,51]). In this case, municipalities with limited experience of innovative EUEDs fail to harness energy savings [42,6] because the management of associated retrofitting processes requires enhanced capabilities and capacities.

H2b: Missing experience with novel technologies (EUEDs/LED) limits engagement in retrofitting activities.

In addition to missing experience, there is a tendency to 'wait' for future improvements of innovative technologies and associated greater savings. This failure to harness current savings has been coined the 'energy efficiency paradox' $[26,57]$. At the municipal level, this tendency to wait for more mature product versions and associated backlogs is particularly pronounced [28] and hence represents a key barrier for innovative EUED diffusion, including lighting [15,34,7].

H2c: Municipalities that perceive new technologies as too innovative tend to refrain from retrofitting activities.

Retrofitting public energy infrastructure requires significant amounts of upfront investments into energy-related technologies that typically have a long payback period $[49,52]$. Investments in innovative EUEDs may therefore be perceived as unprofitable as the result of uncertainty regarding energy savings $[12,42,52]$.

H2d: Budget constraints and/or perceived high investments reduce engagement in retrofitting activities.

We have previously defined lock-in contracts with existing suppliers of conventional technologies as a combination of institutional and economic barriers [42]. These contractors (for example with energy utility companies - EUCOs ${ }^{3}$ and multi-utility companies - MUCOs ${ }^{4}$ ) build on decades of experience of current lighting systems, providing maintenance and potentially selling energy at the same time $[18,19,42]$. Unsurprisingly, our previous research suggests that such lock-in contracts limit the choice of alternative modes of governance [43]. The nature of these contracts may also limit the choice of innovative technologies.

H2e: Contractual lock-in limits retrofitting activities.

Finally, acceptance by the general public represents a salient institutional barrier to technology transitions, especially those that directly affect the public. Prior research has highlighted this as an issue for renewable energy technologies but also for lighting or EUEDs in general $[2,60,61]$.

H2f: Missing public acceptance leads to a lower engagement in retrofitting activities.

\section{Methodology}

\subsection{Research context}

To uncover the factors affecting municipal retrofitting activities and the importance of competition between different modes of governance for accelerating these activities, we analysed public lighting infrastructure retrofits with LED lamps in German municipalities (see also $[42,43])$. As mentioned above, investing in retrofits can alleviate financial constraints in the long run and help municipalities meet climate change targets although debt burden often limits efforts to seek and engage in energy efficiency projects. As mentioned above, German municipal debt amounts to $13.4 \mathrm{~m}$ EUR per municipality in 2016, the

\footnotetext{
${ }^{3}$ EUCOs typically engage in energy generation, supply and distribution and transmission [19].

${ }^{4}$ In the German context, MUCO refers specifically to local 'Stadtwerke', which often provide a wide range of utilities such as gas, electricity and municipal waste management for individual households and companies in a specific geographical region [4].
}

sixth highest ratio in the European Union [13,14].

At the same time, the lighting industry has undergone major shifts from traditional (fluorescent and halogen) lamps towards LED with significant savings in terms of energy and costs $[24,47,7]$. Consequently, implementation of this technology is challenging for both producers and customers $[47,50]$, despite forecasted LED market shares of $70 \%$ by 2020 [33] and the share of LED street lighting predicted to reach a $65 \%$ market share as early as 2018 [30].

In the German case, municipal independence and its federal structure have resulted in diverse mechanisms for the provision of street lighting. $30 \%$ of municipalities provide street lighting in-house, $28 \%$ outsourced the management to EUCOs, another $15 \%$ to MUCOs and $21 \%$ partially outsourced services such as maintenance. $2 \%$ of municipalities use ESCO solutions $[43,58]$.

This paper is the third and final publication of a research project focusing on municipal LED retrofits in Germany funded by the German Federal Ministry of Education and Research (BMBF) and the German Energy Agency (dena). The first publication developed a taxonomy of modes of municipal retrofitting governance based on qualitative research [42]. The second established why local authorities engage with energy performance contracting for retrofitting based on a quantitative survey of German municipalities [43]. What sets this publication apart from the other two is the specific focus on the more basic question of why municipalities do or do not engage in retrofitting in the first place whilst integrating prior evidence and creating a review character. It uses the same example of LEDs as the other two papers and the same quantitative survey as the second paper although the response rate $(8.3 \%)$ and total number of responses (927) is smaller $(11.6 \%$ and 1298 respectively). As opposed to the factors determining municipal engagement with energy performance contracts (EPCs) for retrofitting, this paper provides quantitative evidence of drivers and barriers for energy related public infrastructure modernization (retrofitting) in general.

\subsection{Survey design}

To derive a quantitative research design and model for this study, we conducted an extensive literature review (see Section 2), a qualitative study which involved interviewing 40 experts engaging in the process of retrofitting public street lighting (with LED), and a the previous version of the large-scale quantitative survey $[42,43,58]$. The aim of the present study is to:

- Analyse the status quo of municipal street lighting in Germany;

- analyse modernization trends; and

- quantitatively identify challenges, success factors and barriers regarding the modernization of municipal street lighting.

\subsection{Data collection, sample and data processing}

We collected data on public property retrofitting (in this case: public street lighting) through a large-scale quantitative survey of municipalities. A potential caveat when using this methodological approach lies in the potential presence of common method bias, i.e. gathering all information via one empirical instrument, e.g. survey [39]. Following Testa et al. [55] we adopted several measures to reduce this bias. We minimized item ambiguity in the questionnaire by avoiding vague concepts, complicated syntax and unfamiliar terms. Questions were deliberately kept simple, specific and concise. Experiences with a previous wave of the survey (see [43]) could be used to improve the current set-up. ${ }^{5}$ Finally we also guaranteed the respondents' anonymity.

\footnotetext{
5 The full survey and the codebook are available under https://dx.doi.org/10.5281/ zenodo.1039565. Changes compared to previous version [43] added questions 6, 9, 11, 12, 13, 23, 24, 28; edited questions 15 (added option 'no financial support anymore'), 17
} 
Table 1

Response rates across the sample.

\begin{tabular}{lllll}
\hline Size & Inhabitants & Population & Responses & Response rate \\
\hline Very small & $<5000$ & 8307 & 211 & 2.5 \\
Small & $5000<50,000$ & 2679 & 619 & 23.1 \\
Medium & $50,000<100,000$ & 106 & 54 & 50.9 \\
Large & $>100,000$ & 76 & 43 & 56.6 \\
Total: & & $\mathbf{1 1 , 1 6 8}$ & $\mathbf{9 2 7}$ & $\mathbf{8 . 3 \%}$ \\
\hline
\end{tabular}

In the period between December 2015 and February 2016 all German municipalities were asked to fill out a standardized fully structured online survey (29 questions in 12 groups with an adaptive design). Invitations were sent via postal mail and electronic mail to all German local authorities using a specialised service provider. Of the 11,168 municipal entities in Germany distributed across 16 federal states, 927 responded to our survey, which represents a response rate of $8.3 \%$. This sample is mainly representative in terms of size and states (see Table 1). Very small and small municipalities are under-represented.

We gathered key performance indicators and the level of agreement with statements was determined using a 5 point likert scale, ranging from 1 , strongly disagree, to 5 , strongly agree (see Table A.1). ${ }^{6}$ The investigation content firstly included ownership and management form and the lighting inventory. Secondly, participants were asked about issues regarding lighting modernization (technologies for modernization and success factors/obstacles) and contracting (type of contracting, success factors/ obstacles). Finally, information about competencies and capacities, tools for retrofitting, advice, consulting and support or conditions were requested.

\subsection{Model}

Based on the hypotheses we developed two models for the analysis of municipal retrofits, one for drivers and one for barriers. These models are described in the following sections (Fig. 1).

\subsubsection{Dependent variable}

To analyse the determinants that encourage municipalities to engage in retrofitting activities, we use two questions in the survey. Firstly, participants were asked about retrofitting and modernization activities in the past. Secondly, current and future retrofitting activities were considered. The results of the two questions were aggregated in a three-point scale $(0$ - no retrofitting activities; 1 - retrofitting activities in the past OR present/future; 2 - retrofitting activities in the past AND present/future). At the time of the survey, approximately $75 \%$ of surveyed municipalities were engaging in modernization or were planning to retrofit municipal street lighting. Approximately $85 \%$ had

\footnotetext{
(footnote continued)

(added options ', Power Saving / economic savings', 'Payback / return /profitability', 'Funding or financial support', 'acceptance of local population', political will'), 18 (removed options 'the necessary financial resources for the modernization of the adjacent infrastructure (masts, cables, etc.) are not available', 'there are too high risks vs. potential savings'), 20 (added options 'Minimizing the investment and the necessary borrowing, implementation of a modernization without own investments', 'minimizing the financial risk (long-term calculable costs for energy-saving effect and light quality, transfer of default risk to the Contractor)', 'minimizing the current staffing and other resources of the local authority for the operation and planning of the municipal street lighting', 'use of knowledge from energy service company', there are no drivers/reasons'), 21 (added option ' a contracting solution is uneconomical'), 22 (added options 'engineering company',' lighting company', 'local craft', 'MUCO/EUCO'), 27 (removed option 'local level'), 29 (added options 'No own funds for co-financing', 'missing personnel capacity', 'duration of the procedure is too long, too little information and too little notice of the existing programs'), removed questions $8,19,20,21,27$ (these numbers refers to the old list of questions in [43]).

${ }^{6}$ The full anonymized dataset is available under https://dx.doi.org/10.5281/zenodo. 1039565.
}

modernized their streetlights in 5 years prior to December 2015 February 2016. For our subsequent analysis we proceed in two steps: First we evaluate Model I, which includes municipalities that have not engaged in any retrofitting activities, to find out what role which barriers play. Model II sheds light on the drivers for engaging in retrofitting activities.

\subsubsection{Independent variables}

The independent variables include drivers for retrofitting (such as necessary technical knowledge, potential savings, measurability of the savings, engagement of a consultant and the political will) and barriers to retrofitting (such as missing personnel capacity, and best practices etc.). The drivers and barriers variables have been evaluated on 5 point likert scales. All other variables have been assessed on categorical or binary scales (see Table A.1).

\subsubsection{Control variables}

Finally, we include demographic factors (control variables) that are assumed to influence municipal retrofitting engagement. The presence of an inventory of technologies deployed is assumed to trigger retrofitting activities because it facilitates the calculation of potential savings. General knowledge regarding public street lighting is equally conducive to engaging in any kind of change concerning lighting systems. Management and ownership structure of municipal lighting infrastructure also influence the likelihood to engage in retrofitting activities, e.g. if a municipality owns the lighting infrastructure or if a utility does the maintenance influences the municipality's ability to retrofit the existing infrastructure. Finally, the size of the local authority (inhabitants) determines its capacity to engage in large-scale retrofitting projects. A full list of variables can be obtained from Table A.1.

\subsection{Correlation and regression analysis}

The econometric approach to the data is based upon previous research [43]. To obtain a first indication of the relationships we ran a correlation analysis using dependent and independent variables $[17,5]$. Here we included ownership structure, management of street lighting and states as dummy variables.

In a second step, we determine the categories of modernization activities $(0,1$ or 2$)$ using ordered logistic regression. It enables the calculation of the propensity of a certain case belonging to one category based on discriminant $\mathrm{Z}$ scores which are influenced by values of the independent variables $([1,29]$ We report odds ratios i.e. the probability of belonging to a higher group of the dependent variable categories. An odds-ratio $>1$ suggests that with an increase of 1 unit of independent variable the probability of belonging to a higher group of the dependent variable is greater (i.e. 1 instead of 0 ). Vice versa an odds-ratio $<1$ suggests that with an increase of 1 unit of independent variable the probability of belonging to a higher group of the dependent variable is lower. Overall effectiveness of the model is assessed using $\mathrm{Chi}^{2}$ and (McFadden) pseudo $\mathrm{R}^{2}$ results. The sample sizes of 896 (Model I) and 855 (Model II), which were obtained through the listwise deletion of missing answers from the initial sample, provide a robust basis for the analysis $[1,20]$. Our econometric models can predict the outcome (i.e. to what degree the local authority engages in retrofitting activities) see $\mathrm{Chi}^{2}$ statistic significant at the $1 \%$ level. The fitted model further explains one eight of reasons why a municipality is retrofitting - see McFadden's pseudo $\mathrm{R}^{2}$ of 0.12 and 0.14 [32]. Finally, we investigated the variance inflation factors (VIFs) which reveal no multicollinearity as the mean VIF of 1.49 (Model I) and 1.42 (Model II) are well below the critical value of 5 (see Kutner et al. [29]). 


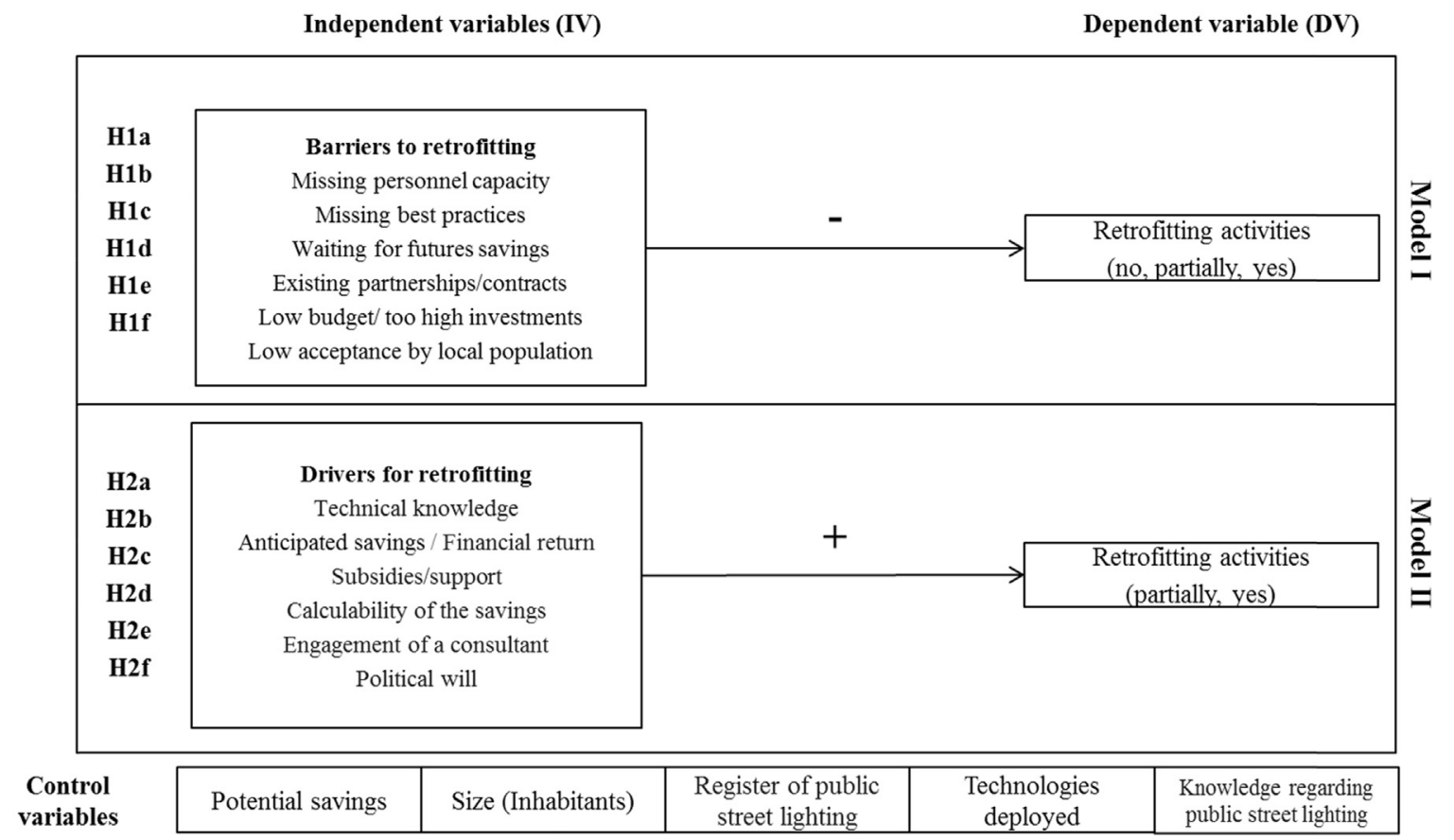

Fig. 1. Models (I and II) for the survey analysis.

\section{Results}

\subsection{Descriptive results}

Respondents expect a high potential for energy savings regarding their street lighting infrastructure: $18 \%$ of respondents expect potential savings of more than $50 \%$; $41 \%$ expect $20-50 \%$. At the same time, rapid modernization faces significant barriers. Local authorities emphasize the budgetary situation and lack of funds available for the comprehensive modernization of street lighting (42\%), the lack of human capacity $(38 \%)$ and perceived high investment or an excessively long payback period (36\%). All other factors are well below 20\%. These correspond to outcomes form the previous survey wave [58]. Smaller municipalities have a greater tendency to wait for increasing technological maturity (with a score of $15 \%$ ) compared to larger municipalities (with an average score of about 7\%).

Around $76 \%$ of local authorities modernise their street lighting predominantly or mostly with LED. At the same time, major disincentives for the use of LED are previous sodium-vapor-lamp (SVL) retrofits and the high price of LED (both 44\%). Approximately 10\% of the larger municipalities continue to rely mostly or mainly on highpressure sodium-vapor lamps (SVL) for modernization. The proportion of local authorities with a majority share of LED lamps in use has increased from $16 \%$ [58] to $20 \%$ between 2014 and 2016. 32\% of municipalities use SVL technologies predominantly or exclusively for street lighting, which is similar to 2014 [58]. This technology is used mainly in medium and larger municipalities. The proportion of old mercury vapor lamps (MVL) has dropped significantly: only $12 \%$ of municipalities still use them primarily or predominantly. In 2014 this figure still stood at $18 \%$ [58]. Today, $70 \%$ of municipalities have minimized the use of MVL lights, up from 61\% in 2014 [58].

Overall, $77 \%$ of local authorities estimate their expertise as excellent $(57 \%)$ or very good $(20 \%)$. This contrasts with $23 \%$ of local authorities who assess their expertise as bad. There has been only a slight increase compared to the survey in 2014 [58]. 56\% of surveyed municipalities state that they systematically manage their inventory using a lighting register. Nearly one third of municipalities have at least an incomplete coverage of their lighting inventory.

Although the vast majority of municipalities retains ownership of its street lighting (76\%), only half of the municipalities (58\%) manages the street lighting (partially or completely) in-house. In $70 \%$ of the municipalities, street lighting is managed wholly or partly by external contractors. But only $18 \%$ of municipalities included an energy saving guarantee within such management contracts.

\subsection{Correlation analysis}

The correlation analysis investigates the relationship between retrofitting activities and ownership, ${ }^{7}$ management ${ }^{8}$ and state of the individual municipalities to detect patterns that might influence the perceptions of drivers and barriers regarding retrofitting. Only 4 out of 16 federal states have significant correlation with retrofitting activities which rules out this variable as major influencing factor. Depending on the ownership structure of street lighting systems, municipalities engage differently in retrofitting activities. Owning the public street lighting is positively correlated with retrofitting activities (significant at the $10 \%$ level) whereas private ownership negatively correlated with retrofitting activities (significant at the $1 \%$ level). This contradicts our previous research highlighting outsourcing/privatisation as a means to overcome barriers to retrofitting [36,43].

On the other hand, doing maintenance and other management activities in-house does not have an influence on retrofitting whereas assigning this task to a local utility (MUCO) is significantly positive correlated with engagement in retrofitting ( $1 \%$ level). However, outsourcing management to a regional or national utility (EUCO) is negatively correlated with modernization (significant at the $1 \%$ and $5 \%$ level respectively).

Table A.2 and A.3 provide the correlation matrix for Model I and II. To avoid multi-collinearity issues we did not include the dummy variables for management, ownership structure and state in the main analysis.

\footnotetext{
${ }^{7}$ Complete ownership of the municipality, complete ownership of EUCO/MUCO, partially privatized, completely privatized.

${ }^{8}$ Own management, partly outsourced, management by MUCO, management by EUCO, energy service contracting.
} 


\subsection{Econometric outcomes}

The outcomes of our baseline model (control variables) show the expected effects: If the municipality keeps track of its infrastructure using a street lighting register the odds are 1.2 higher. This effect is non-significant in Model II. General lighting competencies are also a predictor of higher municipal engagement in retrofitting. It can be deduced from our results that the deployment of older (conventional) lighting technologies such as MVL, SVL and MHL lead to higher retrofitting activities, with this effect being highest for metal halide lamps (1.15-1.47 higher odds of belonging to the higher retrofitting category, depending on the type of lamp currently installed model). Belonging to a higher retrofitting category is also strongly correlated with a higher use of LED during retrofitting. In addition our results show that larger municipalities tend to engage more in retrofitting activities than smaller municipalities. This result should be treated with caution as small and very small municipalities are underrepresented in this sample. Having a larger sample of these group would permit a better evaluation of the problems of small municipalities.

\subsubsection{Barriers to retrofitting (Model I)}

Interestingly, the first hypothesized barrier ( $\mathrm{H} 2 \mathrm{a})$, low personnel capacities, does not appear to imply lower retrofitting activities (Table 2, line b1). Rather the contrary is the case. The higher the personal constraints the more likely it is that the municipality engages in retrofitting activities (with an odds ratio of 1.12 on a $10 \%$ significance level). Our results provide support for $\mathrm{H} 2 \mathrm{~b}$ and $\mathrm{H} 2 \mathrm{c}$, highlighting missing experience with innovative LED technology as well as the perception of future technological improvements as significant barriers to engage in retrofitting activities (Table 2, lines b2-3), especially in the case of LED lighting which represents a major technology shift. For municipalities perceiving these barriers as high, scoring high on retrofitting versus the combined middle and low, the odds are 0.86 and 0.85 times lower respectively compared to municipalities perceiving these barriers as low, if the other variables are held constant.

H2d (Table 2, lines b4-5) relating to budget constraints and high upfront investments into innovative technologies for retrofitting cannot be confirmed in our case. Our research highlights institutional barriers as relevant in the retrofitting process of local authorities (Table 2, lines b6-7). Both existing contracts with suppliers of conventional technologies or energy (H2e) and missing public acceptance (H2f) prevent

Table 2

Results of the ordered logistic regression analysis (Model I).

\begin{tabular}{llll}
\hline & Dependent variable: retrofit & Odds ratio & Std. Err. \\
\hline b1 & Barriers to retrofitting: Personnel capacity & $1.12^{*}$ & $(0.07)$ \\
b2 & Barriers to retrofitting: Missing experience & $0.86^{*}$ & $(0.07)$ \\
b3 & Barriers to retrofitting: Waiting for future savings & $0.85^{* *}$ & $(0.07)$ \\
b4 & Barriers to retrofitting: Budget constraints & 1.11 & $(0.08)$ \\
b5 & Barriers to retrofitting: Too high investments & 1.02 & $(0.08)$ \\
b6 & Barriers to retrofitting: Existing contracts & $0.87^{* *}$ & $(0.06)$ \\
b7 & Barriers to retrofitting: Public acceptance & $0.87^{*}$ & $(0.06)$ \\
8 & Register streetlight present & $1.30^{* *}$ & $(0.15)$ \\
9 & Inhabitants & $1.68^{* * *}$ & $(0.24)$ \\
10 & Competencies Lighting & $1.83^{* * *}$ & $(0.24)$ \\
11 & Existing lighting stock: High pressure mercury vapor & $1.16^{*}$ & $(0.10)$ \\
& lamps (MVL) & & \\
12 & Existing lighting stock: Sodium vapor lamps (SVL) & 1.15 & $(0.10)$ \\
13 & Existing lighting stock: Metal halide lamps (MHL) & $1.30^{* *}$ & $(0.16)$ \\
14 & Existing lighting stock: (Compact) fluorescent lamps & 1.01 & $(0.09)$ \\
15 & Existing lighting stock: LED lamps & 1.02 & $(0.11)$ \\
16 & Potential savings & $1.48^{* * *}$ & $(0.12)$ \\
& Observations (N) & 896 & \\
& Pseudo R ${ }^{2}$ & 0.12 & \\
& Model Chi ${ }^{2}$ (d.f.) & $164.57(16) * * *$ \\
& Initial -2LL & 1242.48 & \\
\hline
\end{tabular}

Notes: ***,****, denote significance at $1 \%, 5 \%$ and $10 \%$ significance levels, respectively; ologit command was used (Stata 13.1).
Table 3

Results of the ordered logistic regression analysis (Model II).

\begin{tabular}{llll}
\hline & Dependent variable: retrofit & Odds ratio & Std. Err. \\
\hline d1 & Drivers for retrofitting: Technical knowledge & $1.23^{* *}$ & $(0.10)$ \\
d2 & Drivers for retrofitting: Anticipated savings & $1.67^{* * *}$ & $(0.30)$ \\
d3 & Drivers for retrofitting: Anticipated financial return & $1.31^{* *}$ & $(0.18)$ \\
d4 & Drivers for retrofitting: Financial support (subsidies) & 1.00 & $(0.09)$ \\
d5 & Drivers for retrofitting: Calculability (Measurement & $0.60^{* * *}$ & $(0.08)$ \\
& \& Verification) & & \\
d6 & Drivers for retrofitting: Engagement of Consultant & $0.85^{* *}$ & $(0.06)$ \\
d7 & Drivers for retrofitting: Political will & 1.02 & $(0.10)$ \\
8 & Register streetlight present & 1.19 & $(0.14)$ \\
9 & Inhabitants & $1.44^{* *}$ & $(0.22)$ \\
10 & Competencies Lighting & $1.71^{* * *}$ & $(0.23)$ \\
11 & Existing lighting stock: High pressure mercury vapor & $1.30^{* * *}$ & $(0.12)$ \\
& lamps (MVL) & & \\
12 & Existing lighting stock: Sodium vapor lamps (SVL) & $1.25^{* *}$ & $(0.12)$ \\
13 & Existing lighting stock: Metal halide lamps (MHL) & $1.47^{* * *}$ & $(0.20)$ \\
14 & Existing lighting stock: (Compact) fluorescent lamps & 1.13 & $(0.11)$ \\
15 & Existing lighting stock: LED lamps & 0.97 & $(0.11)$ \\
16 & Potential savings & $1.44^{* * *}$ & $(0.13)$ \\
& Observations (N) & 855 & \\
& Pseudo R ${ }^{2}$ & 0.14 & \\
& Model Chi ${ }^{2}$ (d.f.) & $155.12(16) * * *$ \\
& Initial -2LL & 918.92 & \\
\hline
\end{tabular}

Notes: ***,***, denote significance at $1 \%, 5 \%$ and $10 \%$ significance levels, respectively; ologit command was used (Stata 13.1).

municipalities from engaging in retrofitting activities. With an oddsratio of 0.87 (everything else held constant), existing contracts are among the severe barriers in our analysis. This also relates to our correlation analysis (see Section 5.2) which reveals that selling public infrastructure to a private third-party contractor is negatively correlated with the modernization of lighting infrastructure. On the other hand, only sourcing the management externally can have positive or negative effects, depending on the contracting party (MUCO or EUCO).

\subsubsection{Drivers for retrofitting municipal street lighting (Model II)}

First, our results show that municipal competencies are indeed a driver for retrofitting activities (Table 3 , line d1). 1 unit increase in competencies leads to a 1.2 increase in likelihood of being in a higher retrofitting category, significant on a $1 \%$ level (H1a).

Both anticipated savings and expected financial return represents strong drivers for a local authority to engage in retrofitting activities (odds ratios of 1.7 and 1.3 on a $1 \%$ and $5 \%$ level respectively, see Table 3, lines $\mathrm{d} 2$ and $\mathrm{d} 3$ ) and thus we can confirm our hypothesis H1b. However, (and surprisingly) M\&V of these savings appears to have a strong negative effect on retrofitting activities, which is contrary to what we hypothesized in $\mathrm{H} 1 \mathrm{c}$. Hence 1 unit increase in the possibility to calculate the savings lead to a 0.6 decrease of belonging to a higher retrofitting category, statistically significant on the $1 \%$ level.

Neither subsidies and support schemes nor the dedicated political will of the local administration (H1d and H1f) play a role in encouraging local authorities to deploy EUEDs (Table 3, lines d5 and d7). Engaging a consultant even has a negative impact on the extent to which a municipality modernises its aging infrastructure (Odds ratio of 0.85 , Table 3, line d6) which contradicts our hypothesis H1e.

\section{Discussion, conclusions and policy implications}

This large-scale survey analysis covering a representative sample of German municipalities adds to the discussion around drivers and barriers for retrofitting using innovative EUEDs [40,55,6]. Potential savings and competencies regarding the EUED (in this case LED) represent the strongest factors encouraging local authorities to engage in retrofitting $[18,19,27]$. However, the 'mode of governance' relating to retrofitting is also correlated with infrastructure modernization. In-house management or a (self-owned) MUCO as partner appear to facilitate the 
Table A.1

Descriptive statistics (Model I and II).

\begin{tabular}{|c|c|c|c|c|c|c|c|}
\hline & Variable & Obs & Mean & Std. Dev. & Min & Max & Measurement \\
\hline & Retrofit & 927 & 1.60 & 0.58 & 0 & 2 & $\begin{array}{l}\text { No retrofitting (0), Past retrofitting OR present/ future retrofitting (1), Past AND } \\
\text { present/ future retrofitting (2) }\end{array}$ \\
\hline d1 & Drivers for retrofitting: Technical knowledge & 884 & 3.82 & 1.07 & 1 & 5 & Likert scale 1-5 (Agreement) \\
\hline $\mathrm{d} 2$ & Drivers for retrofitting: Anticipated savings & 884 & 4.70 & 0.54 & 1 & 5 & ibid \\
\hline d3 & $\begin{array}{l}\text { Drivers for retrofitting: Anticipated financial } \\
\text { return }\end{array}$ & 884 & 4.42 & 0.79 & 1 & 5 & ibid \\
\hline d4 & $\begin{array}{l}\text { Drivers for retrofitting: Financial support } \\
\text { (subsidies) }\end{array}$ & 884 & 4.08 & 1.04 & 1 & 5 & ibid \\
\hline d5 & $\begin{array}{l}\text { Drivers for retrofitting: Calculability } \\
\text { (Measurement \& Verification) }\end{array}$ & 884 & 4.20 & 0.80 & 1 & 5 & ibid \\
\hline d6 & $\begin{array}{l}\text { Drivers for retrofitting: Engagement of } \\
\text { Consultant }\end{array}$ & 884 & 2.97 & 1.28 & 1 & 5 & ibid \\
\hline d7 & Drivers for retrofitting: Political will & 884 & 4.17 & 0.96 & 1 & 5 & ibid \\
\hline b1 & Barriers to retrofitting: Personnel capacity & 927 & 2.82 & 1.37 & 1 & 5 & ibid \\
\hline b2 & Barriers to retrofitting: Missing experience & 927 & 1.98 & 1.07 & 1 & 5 & ibid \\
\hline b3 & Barriers to retrofitting: Waiting for future savings & 927 & 2.00 & 1.09 & 1 & 5 & ibid \\
\hline b4 & Barriers to retrofitting: Budget constraints & 927 & 2.90 & 1.38 & 1 & 5 & ibid \\
\hline b5 & Barriers to retrofitting: Too high investments & 927 & 2.79 & 1.30 & 1 & 5 & ibid \\
\hline b6 & Barriers to retrofitting: Existing contracts & 927 & 1.60 & 1.06 & 1 & 5 & ibid \\
\hline b7 & Barriers to retrofitting: Public acceptance & 927 & 2.09 & 1.18 & 1 & 5 & ibid \\
\hline 8 & Register streetlight present & 927 & 1.41 & 0.73 & 0 & 2 & No (0), partially (1), yes (2) \\
\hline 9 & Inhabitants & 927 & 1.92 & 0.68 & 1 & 4 & $<5.000(1), 5.000<50.000(2), 50.000<100.000(3),>100.000)(4)$ \\
\hline 10 & Competencies Lighting & 927 & 1.96 & 0.66 & 1 & 3 & Poor (1), moderate (2), good (3) \\
\hline 11 & $\begin{array}{l}\text { Existing lighting stock: High pressure mercury } \\
\text { vapor lamps (MVL) }\end{array}$ & 927 & 2.08 & 1.07 & 1 & 5 & $\begin{array}{l}\text { None }(0 \%)(1) \text {, Rarely }(0-20 \%)(2) \text {, Medium }(20-50 \%)(3) \text {, By the majority } \\
(50-80 \%)(4) \text {, Predominantly }(>80 \%)(5)\end{array}$ \\
\hline 12 & $\begin{array}{l}\text { Existing lighting stock: Sodium vapor lamps } \\
\text { (SVL) }\end{array}$ & 927 & 2.93 & 1.19 & 1 & 5 & ibid \\
\hline 13 & Existing lighting stock: Metal halide lamps (MHL) & 927 & 1.52 & 0.66 & 1 & 5 & ibid \\
\hline 14 & $\begin{array}{l}\text { Existing lighting stock: (Compact) fluorescent } \\
\text { lamps }\end{array}$ & 927 & 2.05 & 1.01 & 1 & 5 & ibid \\
\hline 15 & Existing lighting stock: LED lamps & 927 & 2.67 & 1.06 & 1 & 5 & ibid \\
\hline 16 & Potential savings & 896 & 3.60 & 1.00 & 1 & 5 & $\begin{array}{l}\text { No savings potential (1), } 0-10 \% \text { savings (2), } 10-20 \% \text { savings (3), } 20-50 \% \text { savings } \\
\text { (4), More than } 50 \% \text { savings (5) }\end{array}$ \\
\hline
\end{tabular}

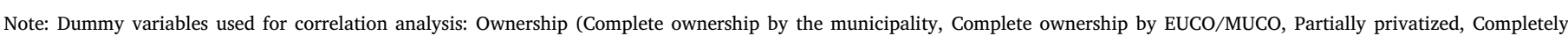
privatized); Management (Partly outsourced, Management by MUCO, Management by EUCO, Energy service contracting); State (16 German regional states).

modernization process whereas partnerships with a regional or national EUCO slow the process as these companies show less interest in retrofitting a local authorities' infrastructure. These general findings are line with (our) previous research $[18,19,42]$.

Based on explicit drivers/barriers analysis among local authority experts, we can confirm the crucial importance of experience with an innovative product $[51,52,6]$. We also find strong evidence of the 'energy efficiency paradox' i.e. the waiting for improved energy efficiency technologies to harness more savings in the future based on the assumption of linear improvements or possibly even greater leaps in technological efficiency instead of investing now to harness current saving possibilities $[26,57]$ in the case of municipal decision making [28]. On the other hand, personnel constraints do not appear to hinder the retrofitting process. This contradicts (our) previous research $[18,42,55]$. A possible explanation lies in the fact that small municipalities engage in smaller retrofitting projects that can be realized despite personnel constraints whereas larger municipalities require more personnel for modernization projects. Interestingly, high upfront investments and budget constraints, highlighted as the 'classic' energy efficiency barriers, do not significantly hinder retrofitting using LED. These findings suggest that some of the economic, behavioural and organisational barriers to energy efficiency (for an overview see [52]) might not be strongly pronounced in the case of LEDs (see also [12,42]). Possible explanations point towards the sample composition of local authorities that have/will modernise/d. LED prices also recently dropped significantly, which makes them more cost-competitive compared to conventional energy-saving technologies which significantly reduces the risk of investment and consequently increases access to capital $[16,52,62,7]$.

Our findings in relation to institutional barriers to modernising aging infrastructure, such as existing contracts and acceptance by the local population, confirm earlier work $[18,19,42]$. Similar to renewable energy installations (i.e. the 'not in my backyard effects' for wind turbines) $[2,60,61]$, acceptance of LED lighting by the local population is critical for successful municipal implementation of the retrofitting process.

Once a local authority has passed the hurdle of engaging in infrastructure modernization, our research identifies several interesting factors that drive the extent of their engagement in retrofitting. A high level of technical knowledge appears to be driving the use of innovative technologies to harness savings. Hence our findings are in line with (our) qualitative evidence regarding retrofitting experience [42] and competencies as relevant for procurement decisions more generally $[55,56]$. Our research further confirms the general notion (see above) that an understanding of savings and resulting monetary benefits are central for local authority decision making in favour of infrastructure modernization [42,52]. Surprisingly, the M\&V aspect of energy efficiency investment appears to hinder as opposed to facilitate modernization [40]. Interestingly, neither subsidies nor the willingness of the local administration to drive the modernization process accelerate the retrofitting process. The latter in particular stands in stark contrast to (our) prior research findings, which overwhelmingly suggest that management and the shaping of values play a crucial role in guiding change $[42,46,52,8]$. Engaging a consultant in the modernization even negatively impacts the extent to which a local authority engages in public street lighting retrofitting. Research in other contexts highlighted intermediaries, facilitators and consultants as conducive $[31,36]$.

In summary, the results suggest that the technological modernization process (and the harnessing of associated savings) in municipalities may be accelerated through the development of local skills and capacities. Transparency at all levels of the process ensures that appropriate 

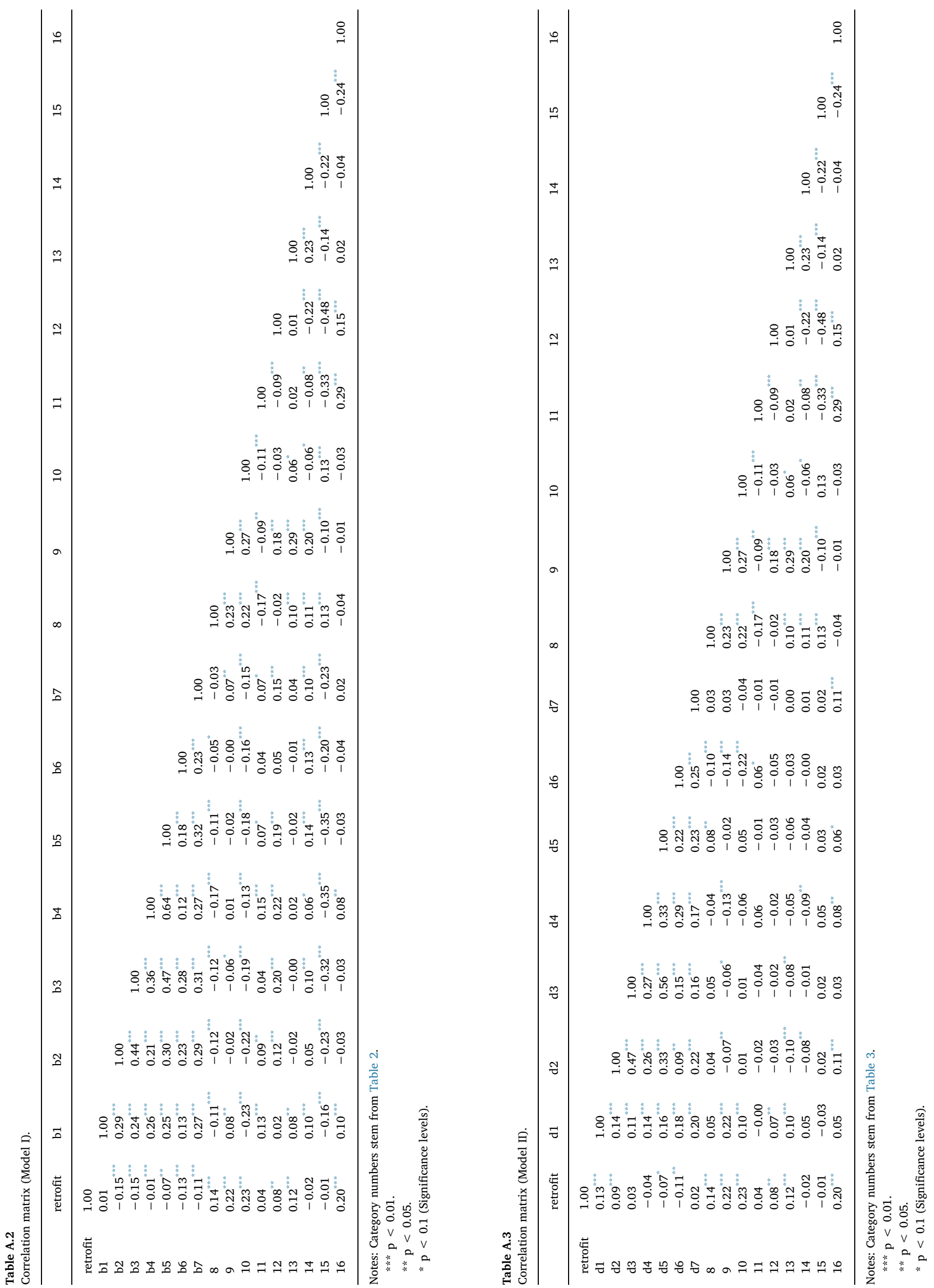
modes of governance can be chosen, which appears to be of particular relevance regarding lock-in contracts with established suppliers such as EUCOs. Measurement and verification $(\mathrm{M} \& \mathrm{~V})$ activities do not appear to be key drivers in this context although transparency of cost savings and the process in general are key drivers for municipalities to engage in retrofitting activities. On the other hand, personnel constraints are not among the significant barriers, rather the contrary is the case. Confirmed barriers include missing experiences with the novel technologies and waiting for improvements of these retrofits ('energy efficiency paradox') that reflect the underlying risk aversion. Abovementioned existing contracts with EUCOs or MUCOs tend to severely hinder local authorities from modernising their infrastructure. Finally, acceptance of the local population needs to be guaranteed in order to roll out the retrofitting measures, even in the case of relatively unobtrusive LED technology.

\subsection{Implications for policy makers}

Based on the discussion of the results, better documentation and communication of the modernization process and statistical analysis of conducted modernization and the energy savings achieved are recommended. This documentation and evaluation of prior experience needs to go beyond the communication of best practice. Instead, there is a need for skills and expertise to reduce perceived investment risks and related uncertainties, especially given that our findings suggest that the risk of investment in LEDs is low and access to capital does not pose a barrier to technology diffusion. Instead of subsidizing the procurement of EUEDs, the rapid generation of knowledge and experience could help accelerate the process of modernization but documentation and facilitation are necessary to harness the benefits without constant reinvention of the wheel.

With the abovementioned measures, a strengthening of (technical or business/market) competency among municipalities and utilities to assess the quality of innovative technologies and possible savings, as well as risks, can be achieved. This is particularly critical regarding the planning phase of modernization projects (database, cost transparency, etc.), tender design, and implementation of modernization projects.

It is also recommended to further develop alternative business models and service offerings (governance arrangements) to overcome institutional lock-ins (see [42]). In relation to product and performance

\section{Appendix}

(See Tables A.1-A3).

\section{References}

[1] Agresti A. Analysis of Ordinal Categorical Data. John Wiley \& Sons; 2010.

[2] Arabatzis G, Myronidis D. Contribution of SHP Stations to the development of an area and their social acceptance. Renew Sustain Energy Rev 2011;15:3909-17. http://dx.doi.org/10.1016/j.rser.2011.07.026.

[3] Bennich P, Schoenen B, Scholand M, Borg N. Test Report - Clear, Non-Directional LED Lamps; 2014.

[4] Betsill MM, Bulkeley H. Cities and the multilevel governance of global climate change. Glob Gov Rev Multilater Int Organ 2006;12:141-59. http://dx.doi.org/10, 5555/ggov.2006.12.2.141.

[5] Cohen J, Cohen P, West SG, Aiken LS. Applied Multiple Regression Correlation Analysis for the Behavioral Sciences. 3rd ed Mahwah, N.J: L. Erlbaum Associates; 2009

[6] Comodi G, Cioccolanti L, Polonara F, Brandoni C. Local authorities in the context of energy and climate policy. Energy PolicyRenew 2012;51:737-48. http://dx.doi org /10.1016/j.enpol.2012.09.019.

[7] De Almeida A, Santos B, Paolo B, Quicheron M. Solid state lighting review Potential and challenges in Europe. Renew Sustain Energy Rev 2014;34:30-48. http://dx.doi.org/10.1016/j.rser.2014.02.029.

[8] de Almeida A, Zissis G, Quicheron M, Bertoldi P. Accelerating the Deployment of criteria, clarifying the possibilities of extending the (energy saving) guarantees might be a fruitful way forward. In addition, a timely clarification of the possibilities to further standardize products and contracts appears desirable [36].

\subsection{Limitations and future research}

As third article from a research project this study is focussing on overall drivers and barriers regarding municipal retrofitting and should therefore represent a sufficiently distinct focus. It complements our other two publications that address modes of governance in general and performance contracting in particular $[42,43]$. This publication could be seen as potentially limited in terms of the cross-sectional nature of the data, the focus on only one market, and possible application for one particular end-use energy demand reduction technology (i.e. LED). Also, the group categories of very small and small municipalities are under-represented in our sample, potentially due to limited capacities to respond to the survey.

In general, more research is required on how experience and competencies can be harnessed and enhanced to ensure that retrofitting takes on the character of a market in its own right. For example based on this dataset, ${ }^{9}$ the effect of municipal retrofitting tools such as technical checklists or comparative calculations schemes as well as different forms of consulting or specific barriers to LED usage on retrofitting activities could be analysed. Also, longitudinal analyses to see how drivers and barriers for innovative EUEDs in the public sector change over time or in different institutional contexts lend themselves to this end. But more importantly, the development of relevant skills and business models accompanying this change need to be monitored to enable more precise intervention.

\section{Acknowledgements}

The authors are grateful for the time and support of the survey participants. The research team would like to thank the German Energy Agency (dena) and Carsten Grohne for their financial support and data provision as part of the research project 'Modernising municipal street lighting'. Valuable comments on earlier versions of the paper were provided by four anonymous journal reviewers.

\footnotetext{
${ }^{9}$ see https://dx.doi.org/10.5281/zenodo.1039565.
}

Solid State Lighting (SSL) in Europe (No. Report EUR 25596 EN).

[9] dena. Energy-Efficient Municipalities [WWW Document]. UR; 2015. 〈http://www. dena.de/en/projects/building/energy-efficient-municipalities.html $\rangle$.

[10] Difu. Finanzierung kommunaler Klimaschutzmassnahmen. Deutsches Institut fuer Urbanistik, Berlin; 2014.

[11] DStGB. Nr. 92 - Öffentliche Beleuchtung, Analyse, Potenziale und Beschaffung. Deutscher Städte- und Gemeindebund; 2010.

[12] Eichhammer W, Ragwitz M, Schlomann B. Introduction to the special issue: financing instruments to promote energy efficiency and renewables in times of tight public budgets. Energy Environ 2013;24:1-26. http://dx.doi.org/10.1260/0958305X.24.1-2.1.

[13] Eurostat. Local government debt [WWW Document]. UR; 2017a. 〈http://appsso. eurostat.ec.europa.eu/nui/show.do?Dataset = gov_10dd_logd\&lang $=$ en $\rangle$ [accessed 23 October 2017].

[14] Eurostat. Local Administrative Units (LAU) [WWW Document]. UR; 2017b. 〈http:// ec.europa.eu/eurostat/web/nuts/local-administrative-units $>$ [accessed 23 October 2017].

[15] Fouquet R, Pearson PJG. Seven centuries of energy services: the price and use of light in the United Kingdom (1300-2000). Energy J 2006;27:139-77.

[16] Gayral B. LEDs for lighting: basic physics and prospects for energy savings. Comptes Rendus Phys 2017. http://dx.doi.org/10.1016/j.crhy.2017.09.001.

[17] Hair J. Multivariate data analysis: a global perspective. 7th ed Upper Saddle River 
N.J., London: Pearson Education; 2010.

[18] Hannon MJ, Bolton R. UK Local Authority engagement with the Energy Service Company (ESCo) model: key characteristics, benefits, limitations and considerations. Energy Policy 2015;78:198-212. http://dx.doi.org/10.1016/j.enpol.2014.11. 016.

[19] Hannon MJ, Foxon TJ, Gale WF. The co-evolutionary relationship between Energy Service Companies and the UK energy system: implications for a low-carbon transition. Energy Policy 2013;61:1031-45. http://dx.doi.org/10.1016/j.enpol.2013. 06.009.

[20] Hosmer DW, Lemeshow S. Introduction to the Logistic Regression Model. Applied Logistic Regression. Hoboken, NJ, USA: John Wiley \& Sons, Inc; 2000. p. 1-30.

21] IEA. Energy Technology Perspectives 2016 - Towards Sustainable Urban Energy Systems. International Energy Agency, Paris; 2016.

[22] IEA. Energy Efficiency Market Report 2014. International Energy Agency; 2014a

[23] IEA. Capturing the Multiple Benefits of Energy Efficiency. International Energy Agency, Paris; 2014b.

[24] IEA. Solid State Lighting Annex: 2013 Interlaboratory Comparison. International Energy Agency; 2013.

[25] Jackson J. Promoting energy efficiency investments with risk management decision tools. Energy Policy 2010;38:3865-73. http://dx.doi.org/10.1016/j.enpol.2010.03. 006.

[26] Jaffe AB, Stavins RN. The energy paradox and the diffusion of conservation tech nology. Resour Energy Econ 1994;16:91-122. http://dx.doi.org/10.1016/09287655(94)90001-9.

[27] Jensen JO, Nielsen SB, Hansen J. Greening Public Buildings: esco-contracting in Danish Municipalities. Energies 2013;6:2407-27.

[28] Jensen JO, Oesten P, Nielsen SB. ESCO as innovative facilities management in Danish municipalities, in: EuroFM 2010: Research Symposium; 2010.

[29] Kutner MH, Nachtsheim CJ, Neter J, Li W. Applied linear statistical models. 5th ed New York: McGraw-Hill; 2005.

[30] LEDinside. The Global LED Street Light Penetration Rate Will Reach About 65\% in 2018? General Commercial Lighting Will Continue to Grow Rapidly [WWW Document]. UR; 2017. 〈http://www.ledinside.com/newsletter/1286〉.

[31] Lemon M, Pollitt MG, Steer S. Local energy policy and managing low carbon transition: the case of Leicester, UK. Energy Strategy Rev 2015;6:57-63. http://dx. doi.org/10.1016/j.esr.2015.02.001.

[32] Long JS, Freese J. Regression Models for Categorical Dependent Variables Using Stata. Stata press; 2006

[33] McKinsey. Lighting the Way: Perspectives on the Global Lghting Market. Second edition McKinsey\&Company; 2012

[34] Mills B, Schleich J. Household transitions to energy efficient lighting. Energy Econ 2014;46:151-60. http://dx.doi.org/10.1016/j.eneco.2014.08.022.

[35] Nolden C, Sorrell S. The UK market for energy service contracts in 2014-2015. Energy Effic 2016:1-16. http://dx.doi.org/10.1007/s12053-016-9430-2.

[36] Nolden C, Sorrell S, Polzin F. Catalysing the energy service market: the role of intermediaries. Energy Policy 2016;98:420-30. http://dx.doi.org/10.1016/j.enpol. 2016.08.041.

[37] Nolden C, Sorrell S, Polzin F. Innovative Procurement Frameworks for Energy Performance Contracting in the UK Public Sector. SPRU Work. Pap. Ser. SWPS 2015-31, 1-34.

[38] Offermann R, Irrek W, Duscha M, Seefeldt F. Monitoring the energy effiicency service market in Germany, ECEEE 2013 Summer Study Proceedings; 2013.

[39] Podsakoff PM, MacKenzie SB, Lee J-Y, Podsakoff NP. Common method biases in behavioral research: a critical review of the literature and recommended remedies. J Appl Psychol 2003;88:879.

[40] Poggi F, Firmino A, Amado M. Assessing energy performances: a step toward energy efficiency at the municipal level. Sustain Cities Soc 2017;33:57-69. http://dx.doi. org/10.1016/j.scs.2017.05.014.

[41] Polzin F. Mobilizing private finance for low-carbon innovation - a systematic review of barriers and solutions. Renew Sustain Energy Rev 2017;77:525-35. http:// dx.doi.org/10.1016/j.rser.2017.04.007.

[42] Polzin F, von Flotow P, Nolden C. Modes of governance for municipal energy ef ficiency services - the case of LED street lighting in Germany. J Clean Prod
2016;139:133-45. http://dx.doi.org/10.1016/j.jclepro.2016.07.100.

[43] Polzin F, von Flotow P, Nolden C. What encourages local authorities to engage with energy performance contracting for retrofitting? Evidence from German municipalities. Energy Policy 2016;94:317-30. http://dx.doi.org/10.1016/j.enpol.2016. 03.049.

[44] Radulovic D, Skok S, Kirincic V. Energy efficiency public lighting management in the cities. Energy, Proceedings of the 5th Dubrovnik Conference on Sustainable Development of Energy, Water \& Environment Systems 36, 1908-1915. doi:10. 1016/j.energy.2010.10.016; 2011.

[45] Rogers E Diffusion of Innovations; 1995, The Free Press; New York, USA.

[46] Salvia M, Leo SD, Nakos C, Maras H, Panevski S, Fülöp O, Papagianni S, Tarevska Z, Čeh D, Szabó E, Bodzsár B. Creating a sustainable and resource efficient future: a methodological toolkit for municipalities. Renew Sustain Energy Rev 2015;50:480-96. http://dx.doi.org/10.1016/j.rser.2015.05.027.

[47] Sanderson SW, Simons KL. Light emitting diodes and the lighting revolution: the emergence of a solid-state lighting industry. Res Policy 2014;43:1730-46. http:// dx.doi.org/10.1016/j.respol.2014.07.011.

[48] Schischke K, Nissen NF, Stobbe L, Reichl H. Energy efficiency meets ecodesign technology impacts of the European EuP directive, in: IEEE International Symposium on Electronics and the Environment, 2008. ISEE 2008. Presented a theIEEE International Symposium on Electronics and the Environment, 2008. ISEE2008, 2008, pp. 1-6. https://dx.doi.org/10.1109/ISEE.2008.4562882.

[49] Schleich J. Barriers to energy efficiency: a comparison across the German commercial and services sector. Ecol Econ 2009;68:2150-9. http://dx.doi.org/10.1016/ j.ecolecon.2009.02.008.

[50] Smink MM, Hekkert MP, Negro SO. Keeping sustainable innovation on a leash? Exploring incumbents' institutional strategies. Bus Strategy Environ 2015;24:86-101. http://dx.doi.org/10.1002/bse.1808.

[51] Sorrell S. Reducing energy demand: a review of issues, challenges and approaches. Renew Sustain Energy Rev 2015;47:74-82. http://dx.doi.org/10.1016/j.rser.2015. 03.002 .

[52] Sorrell S, O'Malley E, Schleich J, Scott S. The Economics of Energy Efficiency: Barriers to Cost-effective Investment. Cheltenham, UK: Edward Elgar Publishing; 2004.

[53] Sovacool BK. The importance of comprehensiveness in renewable electricity and energy-efficiency policy. Energy Policy 2009;37:1529-41. http://dx.doi.org/10. 1016/j.enpol.2008.12.016.

[54] Steinberger JK, van Niel J, Bourg D. Profiting from negawatts: reducing absolute consumption and emissions through a performance-based energy economy. Energy Policy 2009;37:361-70. http://dx.doi.org/10.1016/j.enpol.2008.08.030.

[55] Testa F, Annunziata E, Iraldo F, Frey M. Drawbacks and opportunities of green public procurement: an effective tool for sustainable production. J Clean Prod 2016;112:1893-900.

[56] Uyarra E, Edler J, Garcia-Estevez J, Georghiou L, Yeow J. Barriers to innovation through public procurement: a supplier perspective. Technovation 2014;34:631-45 http://dx.doi.org/10.1016/j.technovation.2014.04.003.

[57] van Soest DP, Bulte EH. Does the Energy-Efficiency Paradox Exist? Technological Progress and Uncertainty. Environ Resour Econ 2001:18. http://dx.doi.org/10. 1023/A:1011112406964.

[58] von Flotow P, Polzin F. Modernisierung der kommunalen Straßenbeleuchtung Erfolgsfaktoren und Hemmnisse der LED-Anwendung sowie von Contracting. Oestrich-Winkel: Sustainable Business Institute (SBI); 2015

[59] Williamson OE. The Economic Institutions of Capitalism. New York: Free Press; 1985.

[60] Wilson C, Grubler A, Gallagher KS, Nemet GF. Marginalization of end-use technologies in energy innovation for climate protection. Nat Clim Change 2012;2:780-8. http://dx.doi.org/10.1038/nclimate1576.

[61] Wüstenhagen R, Wolsink M, Bürer MJ. Social acceptance of renewable energy innovation: an introduction to the concept. Energy Policy 2007;35:2683-91. http:// dx.doi.org/10.1016/j.enpol.2006.12.001.

[62] ZVEI. Die Lichtbranche - Fakten, Forderungen, Zahlen. ZVEI, Frankfurt am Main; 2015. 